\title{
THE NEW ARCHITECTURAL CLASSICISM IN NORTHERN CYPRUS
}

\author{
Marko KIESSEL, Devrim YÜCEL-BESİM, Asu TOZAN
}

Received: 26.05.2011, Final Text: 12.11.2011

Keywords: Post-Modernism; Northern Cyprus; architecture; New Classicism; consumerism.
In the early 1990s, a Post-Modern architectural classicism emerged in Northern Cyprus, a trend which boomed strongly after 2003, the year of a (failed) peace-plan of the United Nations for the divided island. This trend was influenced by developments in Turkey and arriving late, compared to the international Post-Modern movement.

This study aims at a stylistic and semiotic analysis of the Postmoderne in Northern Cyprus. It is based on a comprehensive survey and demonstrates that four international Post-Modern categories, ranging from 'Figurative-', 'Abstract-' and 'Post-Modern-' to 'Ironic-' Classicism, are applicable to Northern Cyprus alike. The majority of local Post-Modern buildings, regardless of to which category they belong, displays a 'non-contextual' Western classicism instead of referring to the Turkish architectural heritage.

The new classicism in Northern Cyprus covers residential, commercial and recreational architecture. 'Figurative Classicism', displaying a nearly canonical application of classical detailing, is employed in a few residential and recreational buildings. 'Abstract Classicism', displaying a strongly reduced classical detailing, and 'Post-Modern Classicism', the biggest category and displaying a highly eclectic, 'freestyle' detailing, have been observed in relation to residential, commercial and tourism/ recreational architecture. Apart from a few residential buildings 'Ironic/ Kitsch Classicism' is related first of all in relation to tourism/recreational architecture.

Whereas the Post-Modern architecture of Istanbul has been interpreted having mainly a historicist character, this paper suggests that in the case of Northern Cyprus the recent Western classicism -like in Chinacommunicates codes which reflect a booming culture of consumerism. Thus the Postmoderne serves as a tool for the promotion of sales and as an instrument for the representation of social status. 
1. Cyprus conflict: Asmussen, 2008, 1-14. 'Annan Plan' and construction-boom: newspaper 'Star', 5 August 2006, http:// www.tumgazeteler.com/?a=1630429 (accessed 17 June, 2009).

2. Post-Modernism in Turkey: Karasözen and Özer (2006, 107-14, 107); Gönen and Özer (2009, 37-50); Türk Mimarları (1999); Altınoluk (2001); Çinici (1999, 78-9, 110-13).

\section{The "concept of a new symbolism in} architecture based on a reversion to the past" which Hanno-Walter Kruft identifies as the common ground between the European NeoRationalists and the American Post-Modern movement (1994, 445), is also evident in the work of several Turkish architects of the 1960s and 1970s. However, the strong references to the Turkish architectural heritage during that period is usually linked to the terms 'historicity' and 'regionalism in architecture' (Yücel, 2005, 141-7), whereas it appeared only logical to Kruft that “(...) the vague concept of Post-Modernism should subsume the Neo-Rationalist movement, even though these Rationalists generally object to such a tendency." (Kruft, 1994, 445). By emphasizing that "Turkish architects also designed Post-Modern buildings by the 1980s" Karasözen and Özer $(2006,107)$ make clear that they do not interpret the wave of 'historicity' in the Turkey of the 1960s to 70s as Post-Modern. It can be assumed that Kruft would do, considering his comparison of the American Post-Modern and the European Neo-Rationalist movement.

3. Map: http:/ / www.cyprus-maps.com/ maps/Cyprus_big.gif (accessed 12 July, 2009), showing Cyprus after 1974. Vokolida is situated north of Famagusta, north-east of Trikomo at the seaside.

4. This study is the deeply revised version of the unpublished conference paper "Different design approaches of contemporary Postmodern architecture in North-Cyprus", presented at the International Semiotics Congress at Girne American University in 2008. On post-modern hotel-casino complexes in Northern Cyprus: Yücel-Besim, Kiessel and Tozan (2010).

5. On the terminology: Krier (1998, 39); Stern (1990a, 59). On the various Post-Modern trends: Jencks (1989, 27-38); Frampton, (1992, 300-5). Both authors do not define HighTech/Productivism as Post-Modern style. Porphyrios (1990, 66), however, defines Deconstruction as a Post-Modern style.

\section{INTRODUCTION}

The island of Cyprus is divided into a Southern Greek-Cypriot and a Northern Turkish-Cypriot region since 1974. In the North, the internationally not recognized Turkish Republic of North Cyprus was founded in 1983. In recent years Northern Cyprus has experienced a remarkable construction boom. These building activities increased noticeably after the (failed) peace-plan, which was initiated by the former UN-General Secretary Kofi Annan in 2003 (1). Since then, the contemporary architecture of Northern Cyprus displays a strong tendency of a PostModern, Western classicism (Yücel-Besim, Kiessel and Tozan, 2010).

A mediating effect on the architectural process in Northern Cyprus by developments in Turkey -resulting in the beginning of a New Classicism in the island's north in the early 1990s- is obvious, as the design of PostModern buildings is often owed to Turkish architects (and developers), even though officially signed by Turkish-Cypriot architects. Thus the Turkish architects remain anonymous (Adanir, 2008, 5-6; Yücel-Besim, Kiessel and Tozan, 2010). In Turkey, the emergence of a Post-Modern (Western) classicism can be traced back to the beginning of the 1980s (2).

The objective of this study is to contribute to the knowledge about the development of contemporary architectural design in Northern Cyprus. It introduces 16 exemplary buildings and the style of their exterior, on the basis of which it suggests an interpretation as to the significance and semantic meaning of the local Post-Modern trends. The buildings concerned are located in Kyrenia (Girne) on the North coast, in the Northern part of the divided capital Nicosia (Lefkoşa), in Famagusta (Gazimağusa) on the East coast and in Vokolida (Bafra) on the Karpas peninsula (3).

This research is based on an architectural survey, on the analysis of reports of the Ministry of Economy and Tourism and on interviews with the Chamber of Turkish-Cypriot Architects (4). The term 'Post-Modern' is understood by the authors as a stylistic definition, corresponding to the term 'modernist', and hereafter signifies only the 'classical' (5). The design analyses refer basically to classifications proposed in 'New Classicism', edited by Andreas Papadakis and Harriet Watson who suggest three design categories, called 'Figurative-', 'Abstract-' and 'Post-Modern Classicism' (Papadakis and Watson, 1990). Additionally the category 'Ironic Classicism', introduced by Robert A.M. Stern is used -in contrast to the authors' previous article on Post-Modern hotel-casino complexes (1990a, 65-111; Yücel-Besim, Kiessel and Tozan, 2010). In Northern Cyprus these design categories are to be found in residential, commercial and recreational architecture.

In this article all locations are mentioned in Greek or English, followed by the Turkish name in parentheses where necessary.

\section{CATEGORIES OF THE NEW CLASSICISM IN NORTHERN CYPRUS}

\section{'FIGURATIVE CLASSICISM'}

The buildings of this category, which is called 'Canonical Classicism' by Robert Stern, display historicist ornamentation (Stern, 1990a, 163-4; 162-85; Jencks, 1987, 217-23). The definition of 'Figurative Classicism' does not only require the display of figurative elements but also the nearly 'canonical' combination of these elements (Stern, 1990a, 163-164). Effectively, this 
6. In Yücel-Besim, Kiessel and Tozan (2010, 107-2), this fact has not been clearly pointed out.

7. Turkish architectural elements, figurative or rather abstract, played a role in PostModern architecture in Turkey since the 1980s. The housing complexes Soyak Sitesi in Istanbul-Göztepe and Platin Konutları in İstanbul-Ulus by Behruz Çinici (1999, 78-9, 110-3), for example, display a clear reference to traditional Turkish architecture. When compared with the architecture of Sedad Eldem and others (Bozdoğan, Özkan and Yenal, 1987), this influence can be traced back even to the 1950s-1960s.

8. Building discussed in: Yücel-Besim, Kiessel and Tozan (2010, 107). Compare the Palazzi Medici-Ricardi and Rucellai: McLean (1994, 120-5); Palazzi Branconi dell'Aquila, Rome, and Canossa, Verona: Murray (1980, $116,149)$.

9. See headings 'Post-Modern

Classicism' /'Freestyle Classicism' and 'Ironic Classicism' / 'Kitsch-Classicism'

All photos taken by the authors.

Figure 1. Çiğdem Çağnan, residence, Nicosia (Lefkoşa), 2005. architecture is rather 'single-coded' and free of 'contradiction', referring to the terms developed by Robert Venturi and Charles Jencks, as the emphasis is put on the revival of the 'old' instead of the combination of the 'old' and 'new' (Jencks, 1987, 330-5; Jencks, 1989, 14). Post-Modern architecture in Northern Cyprus never corresponds to an authentic 'Figurative Classicism' although many buildings expose figurative detailing (6). Only a few residences and two hotels approach the 'figurative-classical'.

So a residence in Nicosia (Çiğdem Çağnan, 2005) demonstrates a rather 'figurative' Turkish classicism in the sense of Jencks' 'Neo-Vernacular' (Figure 1)(1991, 81-4). Residential architecture which exposes a more abstract approach to the Turkish architectural heritage, can be observed occasionally in the island's North (Figure 2)(7). The Colony Hotel and Casino in Kyrenia (Ziya Necati Özkan; 1998-2002) which revives an Italianate Renaissance palazzo creates, overall, a figurative impression despite a few 'abstract-classical' characteristics (Figure 3)(8). Most of the buildings with figurative detailing, however, belong to the categories 'PostModern" or 'Ironic Classicism' (9).
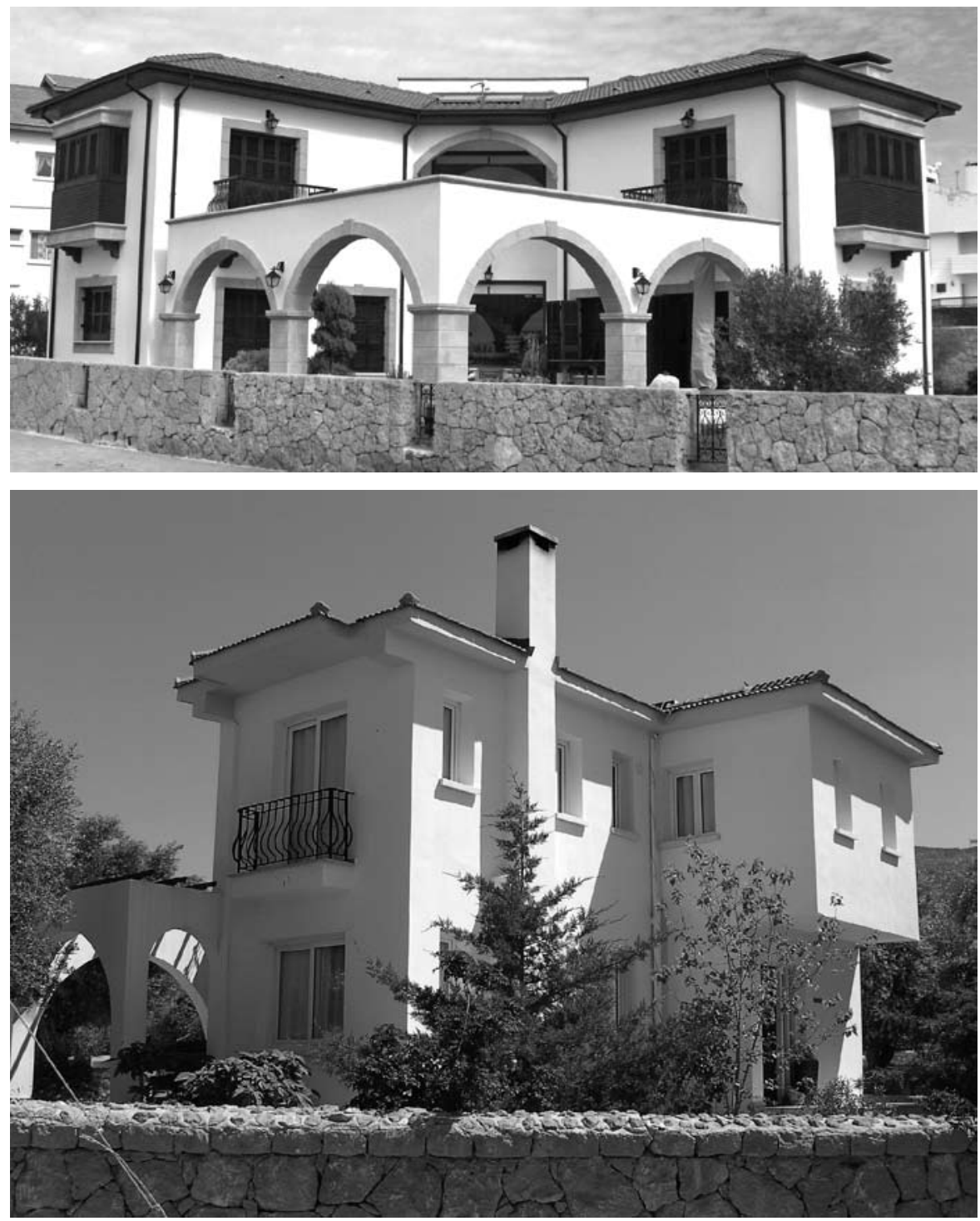

Figure 2. Presently unknown architect, residence, Kyrenia-Kazaphani (GirneOzanköy), c. 2008 
Figure 3. Ziya Necati Özkan, Colony Hotel and Casino, Kyrenia (Girne), 1998-2002.

10. Stern (1990a, 62 (Latent Classicism); 131 (Fundamental Classicism); 132-3 (Aldo Rossi's cemetery in Modena). Examples in İstanbul: Karasözen and Özer (2006, 107-14).

Figure 4. Mehmet Vahip, residence, Kyrenia (Girne), 1994-99.

Figure 5. Mehmet Ülmen, shop, Kyrenia (Girne), 1998.

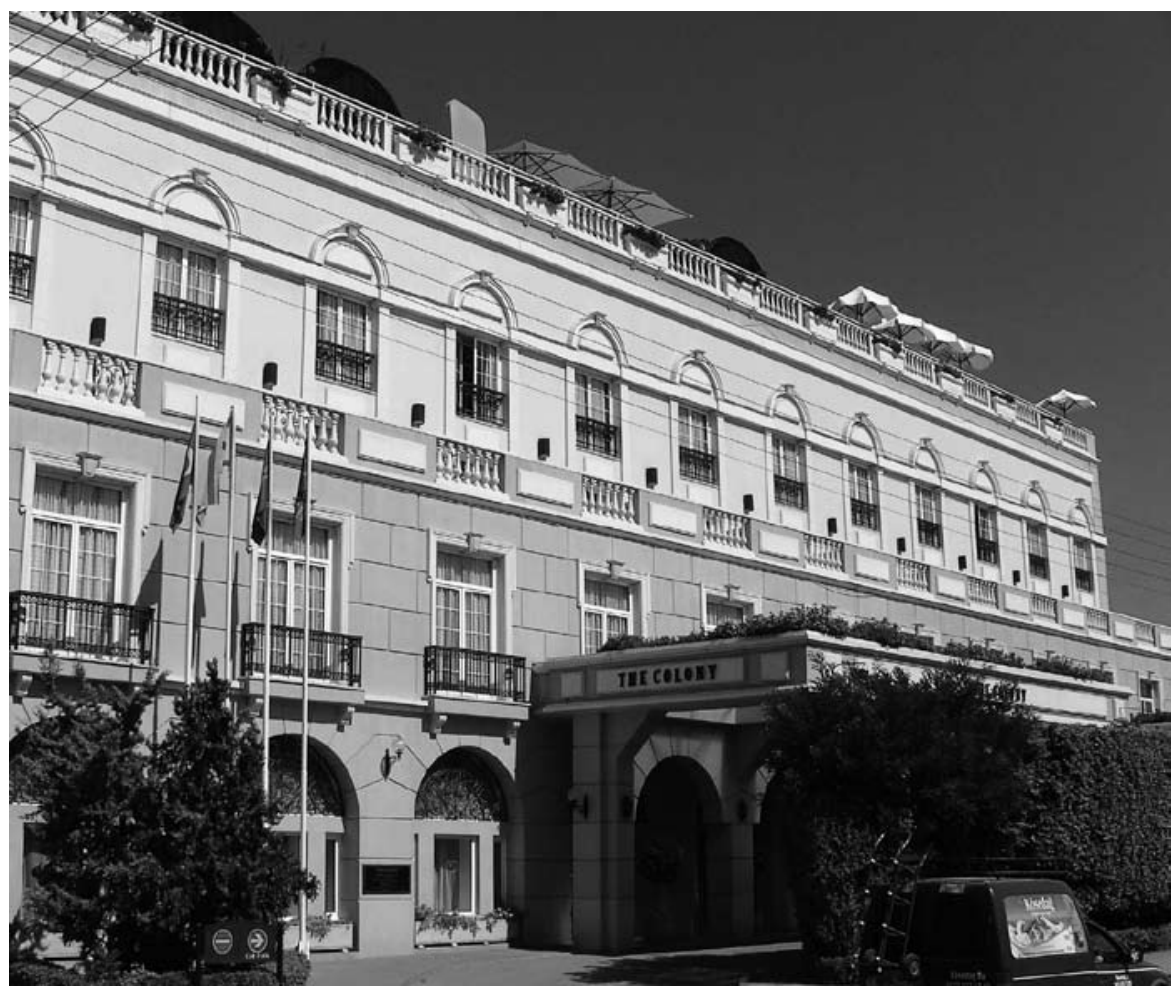

\section{'ABSTRACT CLASSICISM'}

The buildings of this category display a reduced classical architectural detailing, as defined by Robert Stern for his equivalent classification 'Latent Classicism' (1990a, 62, 113, 131). The 'classical' is expressed especially by an austere appearance. A second equivalent category, termed 'Fundamental Classicism', exhibits an even stronger austerity (10). Effectively, 'Abstract Classicism' displays a stronger 'contradiction' or 'double coding' than the previous category - by the combination of classical and modern characteristics, of the 'old and new' (Jencks, 1987, 330-5; Jencks, 1989, 14). According to our observation, the number of 'abstract classical' buildings in Northern Cyprus is considerably higher than figurative ones. The 'abstractclassical' is evident in residential, commercial and hotel architecture.
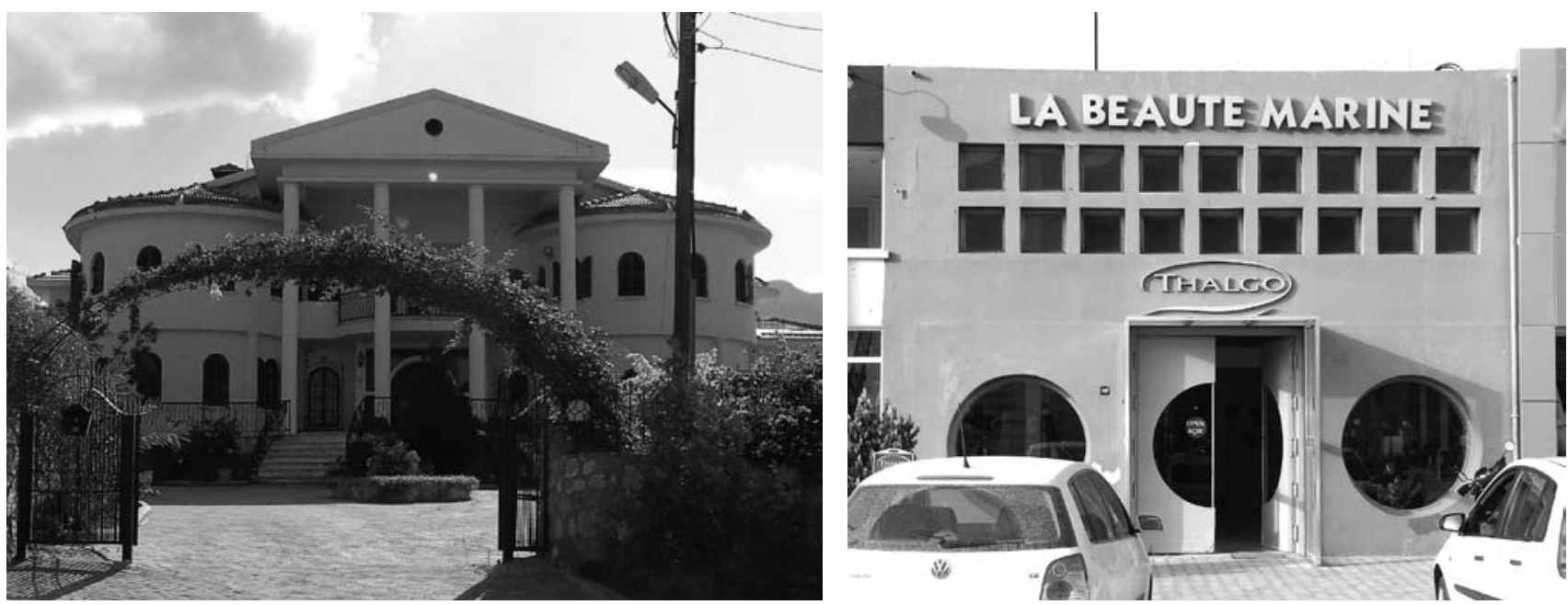


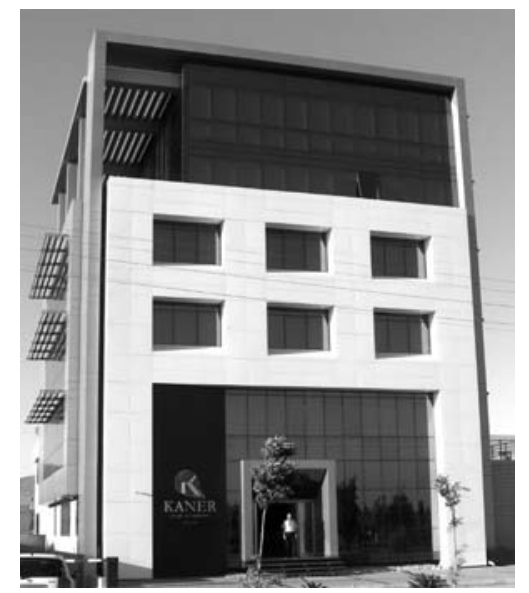

Figure 6. Ziya Necati Özkan, Burak Türsöy, Kaner headquarters, Nicosia (Lefkoşa), 2006.

11. Ground floor 1975 , upper floors and facade design 2006.

12. Figure and discussion in: Yücel-Besim, Kiessel and Tozan (2010, 113, fig. 8).

13. Palladiana by R. Stern and M. Botta: Stern (1990a, 224, 226, 126-7).

14. Papadakis and Watson's category "PostModern Classicism" (1990, 156-83) coincides approximately with Stern's definition

"Modern Traditionalism" (1990, 186-237) and "Ironic Classicism" (1990, 64-111).

Figure 7. Presently unknown architect, apartment building, Kyrenia (Girne), 20042006.

Figure 8. Derya Kara, shop/office, Kyrenia (Girne), 2004.
A residence near Kyrenia (Mehmet Vahip; 1994-99), for example, is characterized by an abstract temple-front (Figure 4). The building might have been inspired by those Italian Renaissance villas which exhibit the motif of the temple-facade, like the Villa Medici by Giuliano da Sangallo in Poggio a Caiano, or the Villa Foscari by Andrea Palladio in Malcontenta (Murray, 1980, 183, 186). The stronger austerity of the facade of a shop building in Kyrenia (Mehmet Ülmen; 1998) is comparable with the designs of 'fundamental classicists' or Neo-Rationalists like Aldo Rossi and Oswald Matthias Ungers (Stern, 1990a, 130-4; Jencks, 1987, 178-89; Kruft, 1994, 445) (Figure 5); as is the facade of the Kaner headquarters in Nicosia (Ziya Necati Özkan, Burak Türsöy; 2006) (Figure 6)(11). Despite its deliberate asymmetry, the 'fundamental-classical' detailing reminds one of O. M. Ungers's Fair Gate building in Frankfurt (Amsoneit, 1994, 66-69). The form of the nine-storey City Royal Hotel and Casino in Nicosia (Osman Sarper; opening 1991), with its classical structure of base, 'body' and 'head' and a central glass curtain, crowned by a glass barrel vault, imitates the 'Palladiana' or 'Serliana' (12). This motif can be encountered frequently in Post-Modern design (13). The high-rise building displays an abstracted classical design to which the modernist glass curtain is less contradictory as might be expected because it is part of the classical, of the Palladiana.

\section{'POST-MODERN CLASSICISM' / 'FREESTYLE CLASSICISM'}

The term 'Post-Modern Classicism' goes back to 1980 and was later also coined 'Freestyle Classicism' by Charles Jencks (Jencks, 1987, 326; Papadakis and Watson, 1990, 156-60). According to Robert Stern's definition of his equivalent category 'Modern Traditionalism', its character is strongly pluralistic and eclectic, integrating also the modernist aesthetics (Stern, 1990a, 63, 187)(14). In effect 'Post-Modern classical' architecture displays a stronger 'contradiction' or 'double coding', a stronger contrasting combination of the 'old' and 'new', when compared to the former categories. This is shown for example by James Stirling's Staatsgalerie in Stuttgart or Michael Graves's Portland Public Service Building (Jencks, 1987, 330-5; Jencks, 1989, 14; Jencks, 1991, 138-43). The majority of Post-Modern buildings in Northern Cyprus belong to this category. The 'Post-Modern-classical' is evident in residential, commercial, educational and hotel architecture.

A building in Templos (Zeytinlik) near Kyrenia (presently unknown architect; 2004-2006) belongs to a frequent type of apartment building in Northern Cyprus which is suitable for a modernist or, due to its
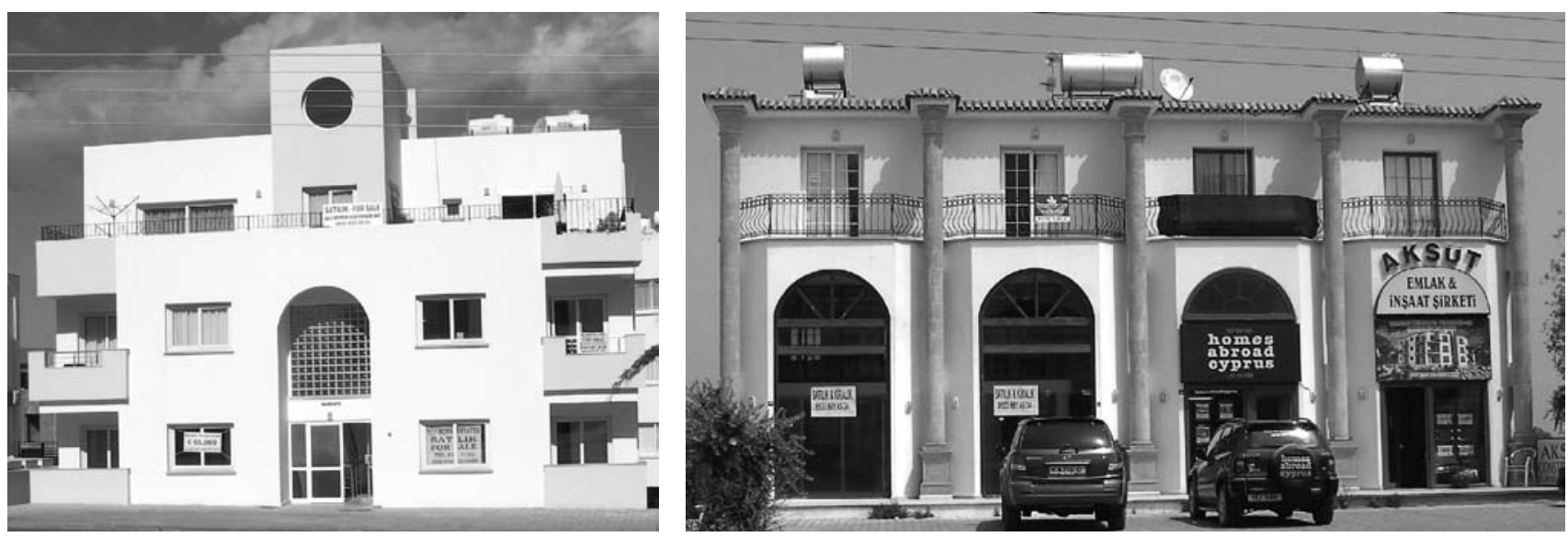


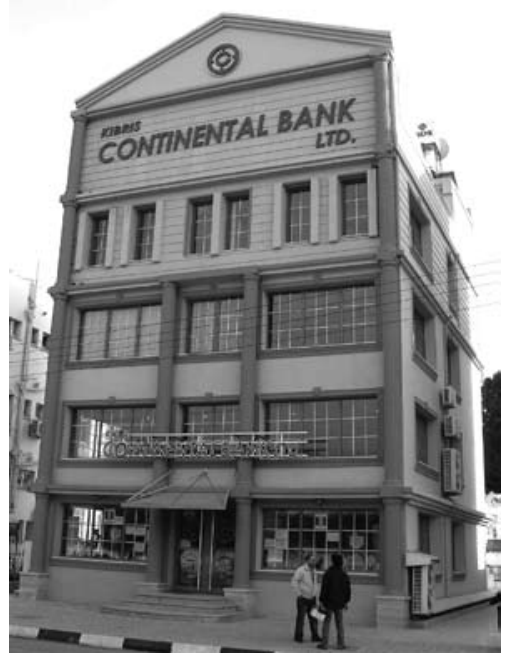

Figure 9. Presently unknown architect, bank building, Nicosia (Lefkoşa), 1997.

15. Rossi: Amsoneit (1994, 38-43); Papadakis and Watson (1990, 140). Krier and Bofill: Stern (1990a, 250-4, 274-9); Jencks (1987, 187-9, 258-65). Similar examples of apartment buildings as in North Cyprus in Turkey: IAA (2005, 70-1, 74-5).

16. Figure and discussion in: Yücel-Besim, Kiessel and Tozan (2010, 117, fig. 13a-b). Grand Azur: Altınoluk (2001, 7-19).

17. Ship motifs in the architecture of Hans Scharoun: Syring and Kirschenmann (2004, 32-7. On ship motifs in modern architecture and on machine aesthetics: Kähler (1981).

18. Figure and discussion in: Yücel-Besim, Kiessel and Tozan (2010, 117-8, fig. 15).

Figure 10a. Alex Brown, student union complex, campus of the Cyprus International University, Nicosia (Lefkoşa), after 1997.

Figure 10b. Alex Brown, faculty building, campus of the Cyprus International University, Nicosia (Lefkoşa), after 1997. symmetrical front elevation, for a Post-Modern design concept (Figure 7). The size of these apartment buildings is much smaller than the typologically different Post-Modern residential complexes of Aldo Rossi, Rob Krier or Ricardo Bofill, a fact that might prove to be a Northern Cypriot or Turkish Post-Modern vernacular (15). The Post-Modern version of the Northern Cypriot type usually demonstrates a rather figurative detailing, in contrast to the austere, lightly classical design in Figure 7. The arcaded facade of a shop/ office building in Kyrenia (Derya Kara; 2004) refers to Roman triumphal arches such as the arch of Constantine I. in Rome, dating back to the 4th century CE (Coarelli, 1989, 162-165). However it does not imitate the historical model despite its figurative detailing (Figure 8). It conveys to be a contemporary building, more than the Italianate palazzo of the Colony Hotel (Figure 3). Being similarly equipped with figurative detailing, the design of a bank building in Nicosia (presently unknown architect; 1997) seems to be an explanation of what R. Venturi meant with his term 'decorated shed' (Venturi, Scott Brown and Izenour, 1977, 87-93)(Figure 9). This is mainly due to the obvious disproportion of the individual elements of its facade. The functional necessities of the building, such as the size of its modern office windows, and the classical character of its facade have apparently not been adjusted to each other.

The 'Post-Modern-classical' is especially evident in two hotel buildings. The four-storey Malpas Hotel and Casino near Kyrenia (Osman Sarper; opening: 2007) is the Post-Modern version of the modernist Maritim Grand Azur Hotel in Marmaris, Turkey (16). It combines modernist and 'abstract-classical' characteristics: The rounded forms of both buildings can be traced back to the machine aesthetics of the 1920s. The form and the rows of circular windows refer to the ocean-liner which used to be a widespread motif in modernist design since the 1920s (17). While the elevation of the Maritim Grand Azur emphasizes (in a modernist manner) the horizontal, the facade of the Malpas is crowned by abstract arches, thus symbolizing a classical arcade. The circular high-rise Golden Tulip Hotel and Casino in Nicosia (Deniz Aybars; 2006-2009) is characterized by the classical structure of base, 'body' and 'head' and the colours red, black and white (18). The circular plan of the building might be related to the classical theory according to which the circle was an ideal form (19). Through its height the building conveys the impression of a tower-like 'Stadtkrone' (20). The Golden Tulip hotel and the Merit Lefkoşa hotel are the only PostModern examples of an international 'Urban Mega-Build' in Northern Cyprus, in contrast to the situation in Turkey (21). Its pictorial appearance is comparable to that of Michael Graves' Portland Public Service Building which has been seen as a Neo-Art Déco design (Stern, 1990a, 82-3).
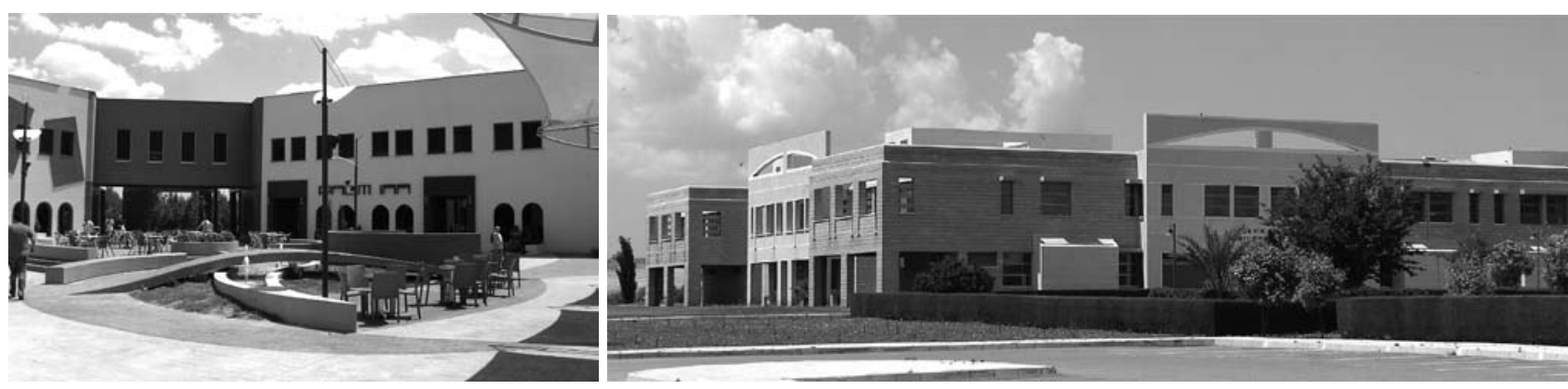
19. On the centralized plan, including the circle: McLean (1994, 116-9).

20. On the tower as 'Stadtkrone': Pehnt (1994, 57-62).

21. Urban Mega-Build: Jencks (1991, 177-80). Merit Lefkoşa hotel: Yücel-Besim, Kiessel and Tozan (2010, 117, fig. 14a-b). 'Urban Mega Build' in Turkey: Türk Mimarları (1999, 30-1, 33-5).

22. Alex Brown's contribution to the campus: http: / / archinodearchitecture.blogspot. com/2009/05/cyprus-internationaluniversity-campus.html (accessed on 20 March, 2010).

23. On modernism in Cyprus see for example: Fereos and Phokaides (2006, 15, fig. 2). CIU business faculty building: http: / / archinodearchitecture.blogspot. com/2009/05/ top-left-rectorate-top-rightcomputer.html; bottom left (accessed 20 March, 2010). M. Konuralp: http:/ / www. archnet.org/library/sites/one-site.jsp?site $\underline{\mathrm{id}=234}$ (accessed 17 June, 2009).

24. Stern (1990a, 61-2, 76-8 (Ironic Classicism and Piazza d'Italia by C. Moore). Compare Jencks (1991, 165-77). The Piazza d'Italia of Charles Moore in New Orleans, for example, may demonstrate the difficulty of defining a border between irony and kitsch. The architecture of the Piazza bears out Moore's classical knowledge. However, the neon-light colors especially may go beyond irony.

25. Krier, 1990, 33). On Krier: Jencks (1987, 190-205).

26. Krier (1998, 185).

27. The Kaya Artemis Resort comprehensively but mistakably discussed under the category "Figurative Classicism" in: Yücel-Besim, Kiessel and Tozan (2010, 111-2, fig. 6a-b). See: Müge Akgün, 'Dünyanın yedi harikasından biri artık beş yıldızlı' [One of the Seven Wonders now has got five stars], Referans Gazetesi, 30 June 2007, www.referansgazetesi.com/ haber.aspx?HBR_KOD=71878\&For Arsiv $=1$ (accessed 17 June, 2009).
The campus of the Cyprus International University near Nicosia (Alex Brown and others; after 1997) demonstrates a 'Post-Modern-classical' mixture of modernist and Post-Modern design (22). The position of the buildings contribute to a certain notion of urban space which becomes especially evident in the square 'piazza' of the Student Union-complex (Figure 10a). It reminds one of the 'medieval piazza' that is enclosed by the buildings of James Stirling's Science Center in Berlin (Jencks, 1987, 274, fig. 9.36). The two faculty buildings of the CIU are square, two-storey blocks with an inner open courtyard and ashlar-cladded exterior facades. Their material and horizontal profile might refer to the Art Déco design of the local modernism of the 1930s-40s. The symmetrical front facade of one faculty building displays a classical version of 'pilotis' which remind one of Mehmet Konuralp's Neo-Rationalist Sağra Residence in Ordu, Turkey (Figure 10b)(23). Despite the abundance of ashlar-cladding, the campus does not display anything 'figurative-classical'. As to Post-Modern campus complexes, Frank Gehry's Law School of the Loyola Marymount University at Los Angeles comes to mind (Stern, 1990a, 90-2). However, its displaced classical elements create an ironic effect which was not intended in the case of the Cyprus International University.

\section{'IRONIC CLASSICISM' / 'KITSCH-CLASSICISM'}

'Ironic Classicism' is a classification by Robert Stern. Being an equivalent to Kenneth Frampton's category 'Populism', it mainly consists of 'PostModern classical' architecture. However, this is said to display an ironical treatment of classical design (Stern, 1990a, 65-111, 67, 76-8; Frampton, 1992, 290-3). Stern implicitly admits the relation between 'Ironic Classicism' and 'Kitsch' saying that 'Ironic Classicism' was, to a big extent, an art for insiders which could develop quickly into something embarrassing and ugly (24). Therefore, it is no coincidence that the Neo-Rationalist Leon Krier, asserts that many Post-Modern buildings are to be understood as Kitsch, due to their "fragmentary nature and provocative eclecticism" (25). The introduction of the term 'Kitsch-Classicism' is therefore a logical consequence.

'Ironic/Kitsch Classicism' is most evident in a residence in Nicosia (presently unkown architect; 2004-2007) (Figure 11). Its kitschy appearance results from the way of application of figurative detailing, just as described by L. Krier: "The decorative refinement of a monumental building will look ridiculous when reduced to the size of a house" (26).

A similar kitschy appearance is created by the Lion's Garden, a club near Famagusta (presently unknown architect; 2006) (Figure 12). Its front is characterized by a protruding pediment which carries a relief scene of female figures, of which the middle group represents the Three Graces, a symbol for beauty. The flanking figures are dancing Maenads, usually associated with Dionysus (Dierichs, 1997, 41-56, fig. 49-50). To understand the symbolic language of the relief requires an educated view, but its content has obviously been carefully chosen, considering the function of the building. Finally, the main building of the Kaya Artemis Resort and Casino in Vokolida (Bafra) (Hasan Erdem Ocakç1; 2007) which is inspired by the younger Artemision of Ephesus, dating back to the 3rd-2nd century BCE (Akurgal, 1987, 74-76, fig. 82-83)(27). Two other buildings within that complex copy the facade of the Roman 'Celsius'-library in Ephesus dating back to the 2nd century CE (Akurgal, 1987, 130-1, pl. 47). Despite the modern structure of the roof and despite the hotel-windows around the cella, the dominating impression of the main building is 'figurative- 
Figure 11. Presently unknown architect, residence, Nicosia (Lefkoşa), 2004-2007.

Figure 12. Presently unknown architect, Lion's Garden Famagusta (Gazimağusa), 2006.
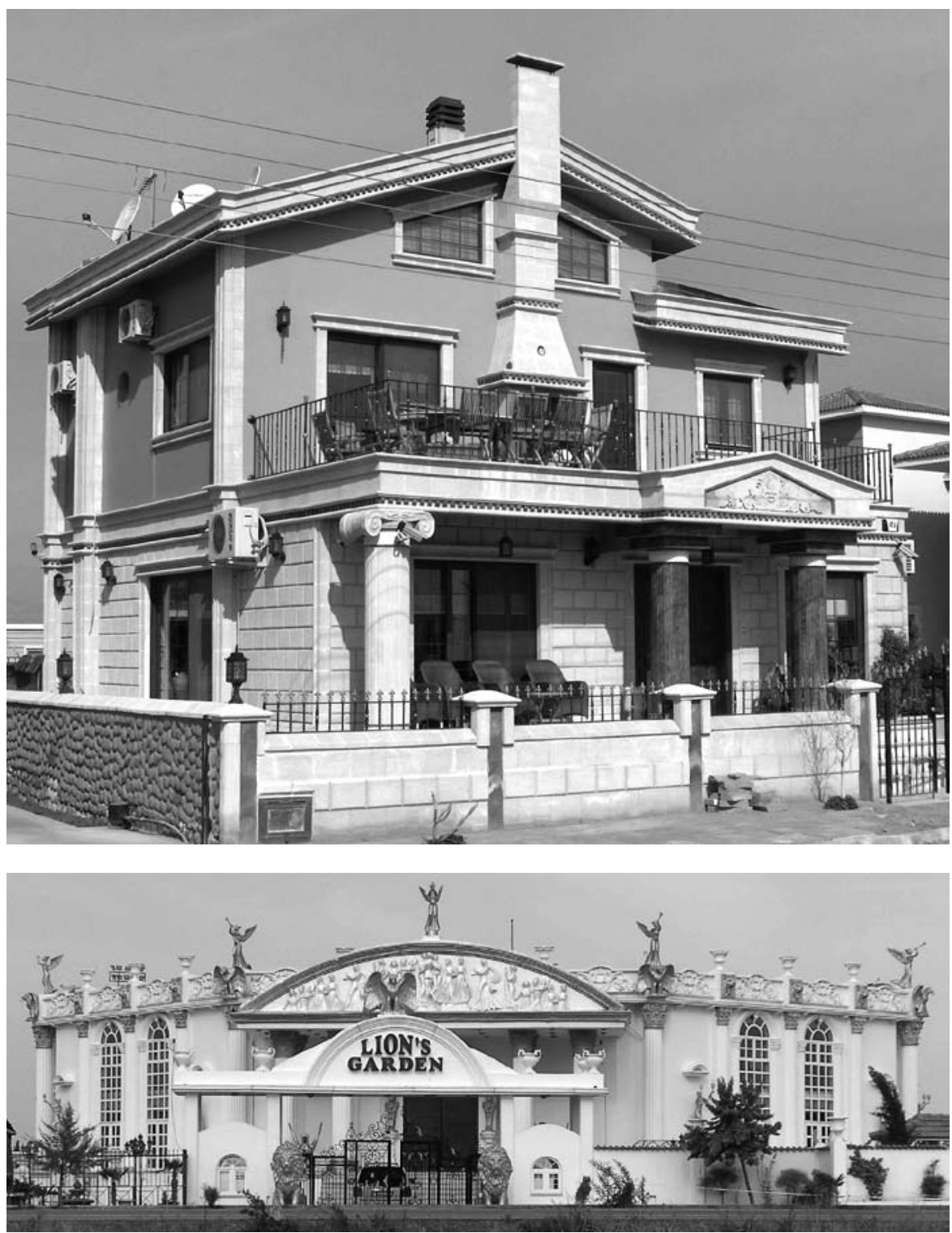

classical'. However, the kitschy effect stems from the dimensions of the 'hotel-temple', the low quality of its decorative detailing and from the "fragmentary nature and provocative eclecticism" of the complex as a whole (Krier, 1990, 33). The Artemis complex belongs to an international trend of concept-hotels in a Las-Vegas-style, such as the Caesar's Palace (28).

\section{THE NEW CLASSICISM IN NORTHERN CYPRUS AND ITS SIGNIFICANCE}

The design of Post-Modern architecture in Northern Cyprus is influenced by the developments in Turkey since the 1980s and by Turkish architects who are not credited officially for their work (29). The latter is the reason for the difficulties of investigating data concerning individual design processes. The local Post-Modernism commenced in the early 1990s: The City Royal Hotel in Nicosia and a residence near Kyrenia are amongst the earliest buildings which can be identified so far (Figure 4)(30). 
Post-Modern architecture in Northern Cyprus is related either to the Res Privata or to the Res Economica, using terms by Leon Krier. Res Privata refers to "the more modest private activities of housing", whereas Res Economica signifies all activities related to commerce and industry. In contrast to the situation in Northern Cyprus, the Res Publica is inherent in the classical design of Western and Eastern public institutions, expressing the "dignity, solemnity [and] grandeur" of the state (31).

The local Post-Modernism is first of all related to residential architecture and includes single-family houses as well as apartment buildings (Figure 1-2, 4, 7, 11). Commercial and business buildings include a considerable number of shop buildings and a few office and bank buildings (Figure 5-6, 8-9). Industrial buildings, i.e. their administrative parts or show-rooms, have hardly been affected by classical design, in contrast to the situation in Turkey (32). Office buildings mainly host estate agencies and construction companies. Additionally, buildings related to tourism and recreation, are to be counted to the architecture of the Res Economica, amongst them are hotel-casino complexes, restaurants and night clubs / discotheques (Figure 3,12 ). The Post-Modern design of a university complex seems to express the 'dignity, solemnity, grandeur' of the Res Publica.

We have observed and defined four Post-Modern design trends in Northern Cyprus. An approach to 'Figurative Classicism', displaying a nearly canonical application of classical detailing, is evident in a few residential and recreational buildings. Commercial buildings have not been recorded so far. 'Abstract Classicism' and 'Post-Modern Classicism', the biggest category, are evident in residential, commercial and tourism/ recreational architecture. Apart from a few residential buildings - of which the most extreme has been introduced here -'Ironic/Kitsch Classicism' has been observed first of all in relation to tourism/recreational architecture (Figure 12).

The design of only a few Post-Modern buildings in Northern Cyprus can convince us by their applied detailing and sophisticated architectural citations: of the examples introduced which are close to a 'Figurative Classicism', the 'Turkish residence' and the 'Italian palazzo', may be mentioned (Figure 1,3). Among the 'abstract-classical' examples a Neo-

31. Krier (1998, 31); Stern (1990b, 31). PostModernism in public Turkish architecture: Türk Mimarları (1999, 60-1, 112, 117, 140$1,162-3,186-7)$; IAA (2005, 62-3). PostModernism in public Chinese buildings: Sizheng Fan (2009, 69-70)

32. Post-Modern industrial architecture in Turkey: Türk Mimarları (1999, 32, 60-2, 94-5, 126-7); IAA (2005, 68, 72-3, 92-3).

33. Tourism Development Plan 1997/98 (Revision in 1999/2000 and 2007). http:// www.ekonomiveturizmbakanligi.com/ upload/pdf/2008.05.26 20-22-27TurizmMaster-Plan-23-5-08.pdf, Güncelleme tarihi (last update): 26 June 2008 (accessed 17 June, 2009).

34. Tourism Development Plan, 6, 24, 26, 63. The critics can be linked to Krier's sketch of the architecture of a Civitas: the 'TRUE CITY' combining monuments with streets and squares $(1998,30)$. The 'true city' of Nicosia, according to Krier, would be found in the 'walled city', the old town.

35. No regulations/guidelines in: Anon. (2005); conclusion from interviews with Chamber of Architects, Northern Cyprus. Rationalist office building stands out (Figure 6). Appealing is the 'PostModern-classical' design of the Malpas hotel that demonstrates the modernist motif of the ocean-liner, of the Neo-Art Déco Grand Tulip hotel and of the campus of the CIU (Figure 10a, 10b).

A considerable increase in Post-Modern design in recent years is obvious. And, due to the ongoing trend in construction, modernist solutions are not expected to play a dominating role in the coming years. The cited examples represent just the peak of a general tendency, which is effectively changing the outlook of the country's architectural environment. Nevertheless, an awareness of and a discussion on design-quality and semiotics of contemporary architecture can be observed within related institutions. The new Tourism Development Plan of 2007, published by the Turkish-Cypriot Ministry of Economy and Tourism, calls for an increase of vernacular and traditional architecture (and thereby questions the current Post-Modern trend) (33). It criticizes the lack of a representative, symbolic architecture for the capital city Nicosia (34). However, as no authority exists, which would play a responsible role in controlling or consulting on architectural design, an eclectic accumulation of styles is very likely to be the architectural future of Northern Cyprus (35). 
36. The Savoy Hotel and Casino in Kyrenia (Girne) discussed in: Yücel-Besim, Kiessel and Tozan (2010, 112, fig.7).

37. Frampton $(1992,306-8)$, on the "dematerialized historicism" of PostModernism. Similar criticism: Kruft, 1994, 442-3). On contextuality: Jencks $(1989,22)$. Western Classicism in a non-contextual environment: Sizheng Fan (2009, 64-74)

\section{8. $\operatorname{Kruft}(1994,442)$.}

39. On Codes etc. in (classical) architecture: Jencks (1987, 291-315); Jencks (1991, 39-62); Gönen and Özer $(2009,38)$.

40. Sizheng Fan (2009, 73-4, 67).

41. Jencks (1990, 220-1 (dialogue with Peter Eisenman)).

42. Tourism: Yücel-Besim, Kiessel and Tozan (2010). International examples: Altınoluk (2001); Altun, Uçar and Cengiz Kaynakçı (2005, 185-93); Henderson (1999); Stern (1990a, 216-7); Jencks (1991, 165-70)

43. Venturi, Scott-Brown and Izenour (1977, 53).

44. Krier $(1990,34)$. On Kitsch and entertainment architecture: Jencks (1991, 165-77).

\section{Krier (1998, 35).}

46. Sizheng Fan $(2009,67)$. Post-Modern shopand mall architecture: Amsoneit (1994, 124-5; Jencks (1987, 249-51, 286-7); Türk Mimarları (1999, 14, 42-3, 104-5); IAA (2005, 84-5). In Northern Cyprus the first Post-Modern mall is being planned (Cyprus Today, 23-26 May 2009 , p. 9).
Noteworthy is the fact that Post-Modern design in Northern Cyprus rarely refers to Ottoman or to Cypriot vernacular architecture, but mainly to the Western classical heritage. Amongst the exceptions are a residence in Nicosia and one hotel-casino complex in Kyrenia (Figure 1)(36). Both approach traditional Turkish architecture in a figurative manner.

Post-Modernism began as a movement that opposed the destruction of local culture and the 'aesthetic brutalism' of the International Style. The founding fathers of Post-Modern architecture called for the respect for the existing - gradually grown - cultural and architectural environment (Jencks, 1987, 27-9; Stern, 1990a, 59-61). However, the New Classicism of Northern Cyprus is part of an international Post-Modernism which is as non-contextual as the International Style (37). Nothing -apart from the few mentioned exceptions- relates this architecture specifically to (Northern) Cyprus, for example to the British colonial classicism. The Greek-Roman tradition is a possible reference, but only in a very general sense, as "(...) models of the past are here treated casually and superficially (...)."(38).

The question whether and which 'codes' are communicated through PostModern architecture in Northern Cyprus, presently cannot be answered concludingly, as sufficient data about design processes do not exist. In the case of İstanbul, it has been asserted that Post-Modern buildings do not "carry the responsibility to necessarily communicate with the user and that it [sic] has mainly a historicist character" (39).

The influential factors of a Western classicism in China, however, eventually may give clues regarding the boom of Post-Modern design and its meaning in Northern Cyprus: In China, Classicism has "acquired a new legacy of symbolizing the culture of entrepreneurship and consumerism", [having become] "an effective tool to promote sales in the popular longing for a Western lifestyle." (40).

The link between (Western) Post-Modernism and economy/consumerism actually dates back to the late 1970s when the 'multi-nationals' in the US discovered classicism as an option for the design of their headquarters - a fact that "killed off" Post-Modernism, according to C. Jencks (41). The culture of consumerism which is part of the Res Economica is first of all evident in Northern-Cypriot tourism- and recreational architecture (42). The 'Kitsch-Classicism' of the Lion's Garden and of the Kaya Artemis complex might communicate the meaning "pleasure-zone" to the public, considering what Robert Venturi wrote about the effect of comparable architecture in Las Vegas (Figure 12):

"For the architect or urban designer, comparisons of Las Vegas with others of the world's 'pleasure zones' (...) suggest that essential to the imagery of pleasure-zone architecture are lightness, the quality of being an oasis in a perhaps hostile context, heightened symbolism, and the ability to engulf the visitor in a new role: for three days one may imagine oneself a centurion at Caesars Palace, a ranger at the Frontier, or a jetsetter at the Riviera (...)"(43).

By transporting the code 'pleasure-zone' the kitschy recreational architecture of Northern Cyprus "(...) is fulfilling its economical function to increase consumption and ease production" (44).

The Post-Modern design of commercial architecture, of supermarkets, shops and malls "(...) will never acquire any significant symbolic value, whatever [their] architectural cladding, (...)"(45). The design of these building types, however, may have equally been meant to support their primary function: "to promote sales" (46). The classicism of commercial 
47. Post-Modern bank- and office buildings: Stern (1990a, 120-1, 128-9, 194-7, 204, 206-7, 214-5, 222-6, 228, 231-3); Jencks (1987, 206-9; 229-34; 236-7; 240-3; 254-6); Türk Mimarlarn $(1999,31,33,60,63,108-9)$.

48. Jencks $(1991,60)$

49. Krier, 1998, 31. Post-Modern university buildings: Amsoneit, 1994, 74-75, 92-93, 120121; Stern (1990a, 86-9, 90-2, 208-10, 222-4); Jencks (1987, 202-5, 282-5); Türk Mimarları $(1999,84,88) ;$ IAA $(2005,104-5)$

50. On 'royal palaces': Krier $(1998,31)$. Consider Leon Krier's remarks on the relation between social status and Kitsch $(1990,34)$. China: Sizheng Fan $(2009,66-7)$ office architecture, in Northern Cyprus especially of estate agencies and construction companies, might have been meant to support their function of promoting product-sales alike: by transporting eventual codes like soberness, reliability and solidity (47). Only a few buildings, like the office in Nicosia, obviously communicate the code 'office' (Figure 6). It displays a glass curtain whose "glass and steel feel cold, impersonal, precise and ordered -the overtones of methodical business, rational planning and commercial transactions" (48).

The importance which societies attribute to public institutions of the Res Publica can be deduced from the architectural expression of their 'dignity, solemnity and grandeur' (49). It may be doubted, however, whether the architecture of private educational institutions, being part of the Res Economica and consumer culture, refers to those values or their design is rather related to the promotion of the product education (Figure 10).

Residential architecture, being part of the Res Privata, is most strongly affected by the New Classicism in Northern Cyprus. It displays the biggest variety of Post-Modern design. Whereas the architecture of apartment buildings still displays a rather modest approach, the houses generally tend to resemble 'royal palaces' (Figure $7,4,11$ ). The booming consumer culture has obviously created a new link between residential design and the longing for a representation of social status. The situation in Northern Cyprus is similar to the case of China in regard to which a relation of social standing, sophisticated lifestyle and Western classicism has been asserted (50).

\section{ACKNOWLEDGMENTS}

The authors owe special thanks to the Chamber of Turkish Cypriot Architects, especially to Mr. Bodamyalızade, and to the Ministry of Economy and Tourism of Northern Cyprus who provided valuable data for this study.

\section{ABBREVIATIONS}

BCE: Before Christ's Era

CE: Christ's Era

IAA: Istanbul Architects Association

\section{REFERENCES}

ADANIR, T. (2008) Ortak Vizeden Haberler, Mimarca (76) 5-6.

AKURGAL, E. (1987) Griechische und Römische Kunst in der Türkei, Hirmer, München.

ALTINOLUK, Ü., ed. (2001) Oteller, Tatil Köyleri, Tasarım Yayın Grubu, İstanbul.

ALTUN, S., UÇAR, A., CENGİZ KAYNAKÇI, E. (2005) Turizm Mimarlığında Temalı Oteller, Alanya Mağusa Sempozyum Bildirileri, Kibris Mimarlar Odası, Nicosia; 185-93.

AMSONEIT, W. (1994) Contemporary European Architects, Taschen, Köln.

ANON. (2005) 2003 Oteller Tüzüğü, Turizm Planlama Dairesi, Nicosia, Northern Cyprus.

BOZDOĞAN, S., ÖZKAN, S., YENAL, E., eds. (1987) Sedad Eldem: Architect in Turkey, Concept Media, Singapore.

COARELLI, F. (1989) Rom. Ein archäologischer Führer, Herder, FreiburgBasel-Wien. 
CURTIS, W.J.R. (1987) Modern Architecture since 1900, Prentice-Hall, Inc., New Jersey.

ÇİNİĊ, B. (1999) Improvisation, Mimarlıkta Doğaçlama, Boyut Matbaacıllk, İstanbul.

DIERICHS, A. (1997) Erotik in der römischen Kunst, Zaberns Bildbände zur Archäologie, Philipp von Zabern Verlag, Mainz.

FEREOS, ST., PHOKAIDES, P. (2006) Architecture in Cyprus between the 1930s and 1970s, Docomomo (35) 15-9.

FRAMPTON, K. (1992) Modern Architecture. A critical History, Thames and Hudson, London.

GÖNEN, E., ÖZER, F. (2009) Neoclassicism in contemporary Post-Modern architecture in Istanbul, itüdergisi/a (8:2) 37-50.

HENDERSON, J. (1999) Casino Design, Resorts, Hotels and Themed Entertainment Spaces, Quarry Books, Gloucester.

IAA (2005) 100 Works-50 Architects, Yap1 Yayın, Istanbul.

JENCKS, C. (1987) Die Postmoderne. Der neue Klassizismus in Kunst und Architektur, Klett-Cotta, Stuttgart.

JENCKS, C. (1989) What is Postmodernism?, Academy Editions, London.

JENCKS, C. (1990) The New Moderns. From Late to Neo-Modernism, Academy Editions, London.

JENCKS, C. (6th ed. 1991) The Language of Postmodern Architecture, Rizzoli, London.

KARASÖZEN, R., ÖZER, F. (2006) The Rational base of Post-Modernism in contemporary Istanbul Architecture, itüdergisi/a (5:2) 107-14.

KÄHLER, G. (1981) Architektur als Symbolverfall: Das Dampfermotiv in der Baukunst, Bauwelt Fundamente 59, Vieweg, Wiesbaden.

KRIER, L. (1990) The Blind Spot, New Classicism. Omnibus Volume, eds. A. Papadakis, H. Watson, Academy Editions, London; 33-5.

KRIER, L. (1998) Architecture: Choice or Fate, Andreas Papadakis Publisher, Singapore.

KRUFT, H.W. (1994) A History of Architectural Theory: From Vitruvius to the Present, Princeton Architectural Press, New York.

MCLEAN, A. (1994) Renaissance Architecture in Florence and Central Italy, The Art of the Italian Renaisssance. Architecture, Sculpture, Painting, Drawing, ed. R. Toman, Könemann Verlag, Köln; 98-130.

MURRAY, P. (1980) Die Architektur der Renaissance in Italien, Gerd Hatje Verlag, Stuttgart.

PAPADAKIS, A., WATSON, H. eds. (1990) New Classicism, Omnibus Volume, Academy Editions, London.

PEHNT, W. (1994) Turm und Höhle, Moderne Architektur in Deutschland 1900 bis 1950. Expressionismus und Neue Sachlichkeit, eds. V. M. Lampugnani, R. Schneider, Gerd Hatje, Stuttgart; 51-67.

PORPHYRIOS, D. (1990) The Relevance of Classical Architecture, New Classicism. Omnibus Volume, eds. A. Papadakis, H. Watson, Academy Editions, London; 53-67. 
SIZHENG FAN, K. (2009) Culture for Sale: Western Classical Architecture in China's Recent Building Boom, Journal of Architectural Education (63:1) 64-74.

STERN, R.A.M. (1990a) Moderner Klassizismus. Entwicklung und Verbreitung der klassischen Tradition von der Renaissance bis zur Gegenwart, DVA, Stuttgart.

STERN, R.A.M. (1990b), 'What the Classical can do for the Modern', New Classicism. Omnibus Volume, eds. A. Papadakis, H. Watson, Academy Editions, London; 31-2.

SYRING, E., KIRSCHENMANN, J.C. (2004) Scharoun, Taschen, Köln.

Tourism Development Plan 1997 / 98, North Cyprus

http:/ / www.ekonomiveturizmbakanligi.com/upload/pdf/2008.05.26 2022-27Turizm-Master-Plan-23-5-08.pdf , Güncelleme tarihi (last update): 26 June 2008 (accessed 17 June, 2009).

Turizm Yapıları, Tatil ve Turizm Tesisleri, Kent Otelleri, Ulaşım Tesisleri (1994) YEM Yayınları, İstanbul.

Türk Mimarları 2000 (1999) Türk Serbest Mimarlar Derneği, Ankara.

VENTURI, R., SCOTT BROWN, D., IZENOUR, St. (1977) Learning from Las Vegas, Cambridge University Press, Cambridge, Mass., London.

YÜCEL, A. (2005) Pluralism Takes Command: The Turkish Architectural Scene Today, Modern Turkish Architecture, eds. R. Holod, A. Evin, S. Özkan, Chamber of Architects of Turkey Publications, Ankara; 11952.

YÜCEL-BESİM, D., KIESSEL, M., TOZAN, A. (2010) Postmodernist HotelCasino Complexes in Northern Cyprus, METU Journal of the Faculty of Architecture (27:1) 103-23.

http:// www.cyprus-maps.com/maps/Cyprus big.gif (accessed 12 July, 2009).

http: / / www.tumgazeteler.com/ ?a=1630429 (accessed 17 June, 2009).

http:/ / archinodearchitecture.blogspot.com/2009/05/cyprus-internationaluniversity-campus.html (accessed on 20 March, 2010).

http: / / archinodearchitecture.blogspot.com/2009/05/top-left-rectoratetop-right-computer.html; (accessed 20 March, 2010)

http: / / www.archnet.org/library/sites/one-site.jsp?site id=234 (accessed 17 June, 2009).

www.referansgazetesi.com/haber.aspx?HBR KOD=71878\&For Arsiv=1 (accessed 17 June, 2009). 
Alınd1: 26.05.2011, Son Metin: 12.11.2011

Anahtar Sözcükler: Post-Modernizm; Kuzey Kıbrıs; mimarlık; Yeni Klasisizm; tüketim kültürü.

\section{KUZEY KIBRIS’TA YENİ MIMMARİ KLASİSİZM}

1990'1 1 yılların başlarında Kuzey Kıbrıs'ta Post-Modern mimari klasisizm ortaya çıkmış; bu eğilim 2003 yılından, yani bölünmüş olan adanın birleştirilmesine yönelik Birleşmiş Milletler' in (başarısız olan) barış planından sonra, yoğun bir artış göstermiştir. Sözü edilen bu eğilimin Türkiye' den etkilenme sonucunda başlaması, uluslararası Post-Modern hareket ile karşılaştırıldığında daha geç tarihlere denk gelmesini açıklamaktadır.

Bu çalışma Kuzey Kıbrıs mimarisinde Post-Modernizmin üslupsal ve semiotik analizini gerçekleştirmeyi amaçlamaktadır. Makale, yerinde inceleme yöntemiyle elde edilen geniş bir veri tabanı üstüne temellenmekte ve uluslararası geçerliliğe sahip "Figüratif", "Soyut", "Post-Modern" ve "İronik" Klasisizmi kapsayan dört kategorinin benzer şekilde Kuzey Kıbrıs'a da uygulanabilirliğini göstermektedir. Hangi gruba dahil olduklarına bakılmaksızın değerlendirilen yerel Post-Modern yapılarda Türk mimari karakterine gönderme yapmak yerine çoğunlukla "noncontextual" (bağlam-d1şı), diğer bir deyişle Batı Klasisizmi sergilendiği ortaya çıkmıştır.

Kuzey Kıbrıs Yeni Klasisizmi, konut, ticaret ve rekreasyon mimarisini kapsamaktadır. Klasik düzeni hemen hemen kuralına uygun olarak kullanan "Figüratif Klasisizm", az sayıda konut ve rekreasyon yapısını kapsayan öneklerde; klasik detayların hissedilir düzeyde azaltılarak kullanıldığ 1 "Soyut Klasisizm" ve en geniş kategoriyi oluşturan yoğun bir eklektisizm ve "freestyle" (serbest üslup) detaylar içeren "Post-Modern Klasisizm" ise konut, ticaret ve rekreasyon/hotel örneklerini kapsayan yapı gruplarında gözlemlenmektedir. İstanbul'da Post-Modern mimarinin yorumlanması sonucu temel eğilimin tarihselci karaktere sahip olduğu saptanmışken, bu makalede, Kuzey Kıbrıs'ta yakın geçmişte büyük artış gösteren Batı Klasisizmi'nin, Çin'deki gelişime benzer bir biçimde, kodlarla iletişim kuran tüketim kültürünü yansıttığı ileri sürülmektedir. Böylelikle "Post-Modernizm"in pazarlanmak istenenin reklamını yapmak için ve sosyal statü temsilinin ifadesinde başvurulan bir araç olarak kullanıldığ 1 saptaması yapılmaktadır.

MARKO KIESSEL; B.A., PhD in Archaeology

Studied Classical Archaeology, Art History and History in Trier, Köln and Bologna. Has Ph.D. in Classical Archaeology and adjunct scholar at the Universität Trier (2005). Since 2006, Assistant Professor at the Cyprus International University. Has research on late Roman, modern and post-modern architecture, Roman pottery and architectural sculpture. mkiessel@ gmail.com

DEVRIM YÜCEL BESIM; B.Arch, M.Arch, Ph.D.

Has Bachelor's and Master degrees in Architecture from METU (1992; 1995), and a Ph.D. in Landscape Architecture from Ankara University (2007) Practiced in different architectural projects from 1992 to 2005 . Has been employed at Girne American University from 2005 on. Has research on postmodern architecture, traditional Turkish housing, urban design, spatial organization. devrimyb@yahoo.com

ASU TOZAN; B.Arch, M.Arch, Ph.D.

Has Bachelor's in Architecture from Eastern Mediterranean University; Master's and Ph.D. in Architecture from ITTU (2000; 2008). Her doctoral thesis is titled "Urbanization and Architecture in Cyprus as an Example of Colonial Modernization (1878-1960)". Assistant Professor at Eastern Mediterranean University, since 2011. Has research on modern and postmodern Cypriot architecture. asu.tozan@emu.edu.tr 